\title{
PERAN CITRA DESTINASI MEMEDIASI PENGARUH $E$-WOM TERHADAP NIAT BERKUNJUNG KEMBALI WISATAWAN (Studi Pada Obyek Wisata Taman Edelweis Bali)
}

\author{
I Putu Hari Budi Utama ${ }^{1}$ \\ I Gusti Ayu Ketut Giantari \\ ${ }^{1,2}$ Fakultas Ekonomi dan Bisnis, Universitas Udayana (Unud), Bali, Indonesia \\ email: putuhari21@gmail.com
}

\begin{abstract}
ABSTRAK
Penelitian ini bertujuan untuk menjelaskan peran citra destinasi dalam memediasi pengaruh $e$ WOM terhadap niat berkunjung kembali wisatawan di obyek wisata Taman Edelweis Bali. Jumlah sampel yang diambil sebanyak 128 wisatawan domestik yang sudah pernah berkunjung ke obyek wisata Taman Edelweis Bali dengan metode purposive sampling yang memiliki kriteria merupakan warga negara Indonesia, sudah berusia 17 tahun ke atas, dan pernah berkunjung ke obyek wisata Taman Edelweis Bali. Pengumpulan data dilakukan dengan penyebaran kuesioner. Teknik analisis data yang digunakan adalah analisis jalur (Path analysis) dan uji Sobel. Hasil penelitian ini menunjukkan bahwa variabel $e$-WOM berpengaruh positif signifikan terhadap niat berkunjung kembali wisatawan. Kemudian variabel $e$-WOM berpengaruh positif signifikan terhadap citra destinasi, dan variabel citra destinasi berpengaruh positif signifikan terhadap niat berkunjung kembali wisatawan. Selain itu, variabel citra destinasi juga memediasi secara parsial pengaruh $e$-WOM terhadap niat berkunjung kembali wisatawan.
\end{abstract}

Kata kunci: $e-W O M$, citra destinasi, dan niat berkunjung kembali wisatawan

\begin{abstract}
This study aims to explain the role of destination image in mediating the effect of e-WOM on the intention to revisit tourists in Bali's Edelweis Park. The number of samples taken was 128 domestic tourists who had visited the Bali's Edelweis Park tourism object with a purposive sampling method that had criteria as Indonesian citizens, aged 17 years and over, and had visited the Bali's Edelweis Park tourism object. Data was collected through questionnaires. The analysis technique used is Path analysis and Sobel test. The results of this study indicate that the $e$-WOM variable has a positive and significant effect on the intention of revisit tourists. Then $e$ WOM variable has positive and significant effect on destination image, and destination image variable has positive and significant effect on tourist revisit intention. In addition, the destination image variable also partially mediates the effect of e-WOM on the intention of revisit tourists. Keywords: e-WOM, destination image, and intention to revisit tourist
\end{abstract}




\section{PENDAHULUAN}

Kemajuan teknologi informasi seakan tak terbendung dan mempengaruhi kehidupan masyarakat. Berbagai aktivitas tidak terlepas dari campur tangan teknologi informasi yang senantiasa saling melengkapi dan menguntungkan. Aktivitas ekonomi dan bisnis yang merupakan kegiatan pokok manusia tentunya selalu mengoptimalkan penggunaan sumber daya guna mendapatkan keuntungan yang maksimal. Salah satunya penggunaan teknologi informasi yang tepat sasaran dan menjangkau semua pelaku usaha. Teknologi informasi telah menjadi instrumen penting bagi semua pelaku bisnis, terlebih bagi mereka yang mengandalkan kekuatan promosi untuk menarik perhatian calon konsumen. Pengaplikasian teknologi informasi sangat sesuai dengan kebutuhan saat ini, karena memudahkan semua pihak dalam menjalankan aktivitas bisnis, termasuk aktivitas pemasaran.

Belakangan ini isu pemasaran menjadi hangat diperbincangkan. Berbicara mengenai pemasaran tentu berkaitan dengan perilaku konsumen. Produsen semakin menyadari pentingnya mengetahui perilaku konsumen (Priansa, 2017:62), karena menggambarkan pendekatan proses pembuatan keputusan, sebelum pembelian dilakukan sampai setelah pembelian terjadi (Suprapti, 2010:4). Pernyataan ini sejalan dengan definisi yang diungkapkan oleh Sumarwan (2004:26) yang menjelaskan perilaku konsumen didorong oleh proses psikologis dan tindakan sebelum terjadinya pembelian, ketika menggunakan barang dan jasa serta proses evaluasi setelah aktivitas-aktivitas tersebut.

Keberadaan teknologi informasi turut mempengaruhi perilaku konsumen. Putri dan Sukawati (2019) menjelaskan adanya perubahan interaksi antarkonsumen sebagai akibat dari perkembangan teknologi yang semakin pesat. Penggunaan teknologi perlahan mengubah aktivitas masyarakat. Transaksi bisnis yang sebelumnya dilakukan secara konvensional (face to face), kini berubah ke arah yang lebih modern dengan media elektronik maupun online tanpa harus bersentuhan atau bertatap muka langsung. Aktivitas pemasaran tentunya dibutuhkan oleh semua pelaku bisnis, baik yang bergerak pada sektor perdagangan maupun sektor jasa. Kehadiran teknologi informasi semakin memudahkan semua pihak untuk memasarkan produk yang dimiliki. Salah satu dari sekian sektor yang merasakan manfaat teknologi informasi ini adalah sektor pariwisata.

Sektor pariwisata tidak terlepas dari cakupan kemajuan teknologi informasi. Bisnis pariwisata senantiasa selaras dengan perkembangan zaman dan globalisasi. Penerapan teknologi informasi berbasis elektronik maupun online sudah menjadi sesuatu yang wajib dijalankan oleh pelaku-pelaku pariwisata. Penggunaan teknologi mampu menekan biaya operasional seperti biaya promosi yang menjadi kekuatan utama pada sektor ini. Maka dari itu penyampaian informasi harus gencar dilakukan dengan metode konvensional maupun melalui media digital - online. Apalagi penyampaian informasi antara produsen dan konsumen pada sektor pariwisata telah mengalami perubahan dikarenakan peningkatan penggunaan internet oleh sebagian besar penduduk (Mulyati dkk., 2018), hal ini diperkuat dengan informasi yang dihimpun dari tekno-kompas.com tentang penetrasi penggunaan internet di Indonesia yang meningkat di tahun 2019. Data pengguna internet pada bulan Maret - April 2019 telah mencapai 64,8 persen, yang berarti bahwa sebanyak 171,17 juta jiwa penduduk Indonesia sudah terjangkau oleh 
internet. Penggunaan internet oleh sebagian besar penduduk Indonesia memberikan gambaran bahwa penduduk saat ini telah beralih menggunakan media elektronikonline dalam menjalankan segala aktivitasnya, termasuk aktivitas pemasaran pariwisata.

Penggunaan media elektronik dan internet telah merubah pola komunikasi dan penyebaran informasi perusahaan kepada konsumen (Mulyati dkk., 2018). Kehadiran media elektronik dan internet dengan fitur interaksi sosial secara online telah memudahkan semua pihak dalam menjalankan aktivitas-aktivitas yang berhubungan dengan bisnis, pemasaran produk, pencarian informasi serta referensi gaya hidup, dan lain sebagainya. Media komunikasi elektronik berkontribusi dalam penyebarluasan informasi pembangunan, termasuk sebagai sarana promosi wisata (Mulyati dkk., 2018).

Perkembangan terbaru dalam teknologi komunikasi elektronik telah menyebabkan munculnya electronic word of mouth (e-WOM) yang memungkinkan individu berbagi pendapat dan pengalaman mereka dengan orang lain melalui saluran komunikasi elektronik, seperti email, blog, networking, room chat, online review, dan situs web dengan informasi yang dibuat oleh pelaku usaha menjadi instrumen yang kuat untuk keputusan promosi dan komunikasi (Ishida et al., 2016). Darmawan dan Nurcaya (2018) setuju bahwa internet menciptakan pola berkomunikasi secara elektronik sebagai paradigma baru pada verbal communication.

Keberadaan internet menyebabkan WOM berkembang menjadi $e$-WOM (Putri dan Sukawati, 2019) yang memuat ulasan positif maupun pernyataan negatif tentang suatu produk atau organisasi bisnis melalui situs web atau jaringan internet (Hennig-Thurau et al., 2004). Menurut Prayogo dan Kusumawardhani (2016), eWOM merupakan media komunikasi informal yang ditujukan kepada konsumen menggunakan teknologi berbasis internet. $E$-WOM memiliki fitur unik dibandingkan dengan tatap muka tradisional, mudah diukur dan dapat dikuantifikasi serta diamati (Baber et al., 2016). Torlak et al. (2014) menyebutkan bahwa konsumen mendapatkan informasi terkait penggunaan produk, perusahaan dan layanan perusahaan melalui teknologi berbasis internet dan komunikasi elektronik (e-WOM).

Komunikasi secara elektronik mampu memberikan informasi yang meyakinkan kepada konsumen. $E$-WOM tergantung pada informasi dan konsumen (Knoll, 2016). Semakin banyak informasi positif tentang produk atau layanan tersebut, maka perusahaan akan meraih keuntungan dari interaksi berbasis elektronik online ini (Phang et al., 2013). Informasi yang positif mengenai suatu produk tentunya akan berdampak pada eksistensi perusahaan. Sebagai contoh ulasan positif tentang suatu obyek wisata mampu menggugah niat calon wisatawan melakukan perjalanan wisata atau kembali berkunjung ke destinasi wisata. Secara sederhana, melalui $e-W O M$ calon wisatawan bisa menentukan sikap dan niat melakukan kunjungan kembali ke suatu destinasi wisata.

Niat merupakan faktor motivasi yang mendorong seseorang melakukan sesuatu (Zarrad dan Debabi, 2015). Dorongan yang kuat, ditambah penilaian positif tentang produk akan mempengaruhi niat seseorang (Kotler, 2000:165). Niat berkunjung kembali adalah kesediaan untuk berkunjung ke suatu destinasi atau 
obyek yang sudah pernah dikunjungi kembali (Abubakar et al., 2017). Niat mengunjungi kembali menekankan wisatawan untuk mengunjungi kembali suatu destinasi wisata dalam jangka waktu tertentu (Ferns dan Walls, 2012). Niat berkunjung kembali didasarkan pada pengalaman yang dirasakan wisatawan selama waktu tertentu sehingga menimbulkan kesan tentang suatu destinasi dan mempengaruhi perilaku dan keputusan akhir (Whang et al., 2016). Niat mengunjungi suatu daya tarik wisata ditentukan oleh informasi, pengetahuan, tanggapan, dan kehandalan sumber yang diacu oleh konsumen (Gruen et al., 2006). Media komunikasi elektronik berperan penting dalam penyerbarluasan informasi wisata. Berdasarkan informasi yang dihimpun dari Detik.com, wisatawan mencari ide/referensi wisata melalui situs web dan jejaring sosial seperti Facebook, Instagram, Twitter yang merupakan media komunikasi elektronik saat ini. Informasi yang termuat pada media sosial (berupa foto, video, atau tulisan) tersebut mampu mempengaruhi dan mengubah rencana berlibur wisatawan. Fenomena ini menarik untuk dicermati, sebagai akibat dari aktivitas pemasaran secara elektronik - online, dan mempengaruhi niat berkunjung wisatawan, ataupun kunjungan kembali ke suatu destinasi wisata.

Pemasaran dengan $e$-WOM tidak serta merta mampu mengundang wisatawan untuk berkunjung kembali ke obyek wisata. Persepsi dan evaluasi wisatawan yang sudah pernah berkunjung akan menentukan citra dari pada destinasi wisata. Semakin baik citra destinasi tersebut, maka semakin meyakinkan wisatawan untuk berkunjung kembali. Maka dari itu citra destinasi juga memegang peranan penting dalam menarik niat wisatawan untuk berkunjung kembali.

Citra (image) merupakan keseluruhan keyakinan, sikap dan kesan individu atau kelompok yang dipegang terhadap destinasi wisata atau aspek suatu destinasi (Weaver dan Lawton, 2014:406). Citra (image) akan membentuk persepsi dan penggambaran mengenai objek, sehingga seseorang/konsumen dapat memberikan penilaian tentang objek tersebut. Citra yang baik merupakan salah satu indikator penentu keberhasilan perusahaan dalam mengembangkan produk yang dimilikinya. Produk yang berupa barang maupun jasa selalu mengedepankan image, termasuk destinasi wisata.

Citra destinasi merupakan sebuah pengetahuan individu dan keyakinannya terhadap sebuah destinasi pariwisata yang dipersepsikan atau dievaluasi (Rai Utama, 2016:335). Fletcher et al. (2018:616) mendefinisikan citra destinasi sebagai sebuah kesadaran individu tentang suatu tempat tujuan yang terdiri dari evaluasi kognitif dari pengalaman, pembelajaran, emosi dan persepsi. Proses seleksi yang didasarkan pada informasi menghasilkan kesan dari variasi produk, atribut dan daya tarik yang dikombinasikan sehingga memunculkan citra yang baik dari suatu destinasi (Whang et al., 2016). Seaton dan Bennett (1996) dalam Setiawan dkk. (2014) mendefinisikan citra destinasi (destination image) sebagai seperangkat pengetahuan dan gambaran suatu destinasi wisata oleh wisatawan yang terdiri dari informasi geografi, infrastruktur, populasi, sejarah, budaya, iklim, penilaian atraksi, keamanan dan lain sebagainya. Citra destinasi merupakan persepsi seseorang tentang produk, benda dan perilaku, serta peristiwa yang didorong oleh keyakinan, perasaan dan serangkaian tujuan dari suatu destinasi atau perjalanan wisata tertentu (Stylos et al., 2016). Citra destinasi mampu mempengaruhi niat berkunjung kembali 
wisatawan. Begitupun dengan $e$-WOM yang mempengaruhi niat berkunjung kembali wisatawan dan citra destinasi itu sendiri.

Melalui pernyataan tersebut dapat dibangun sebuah kerangka konseptual yang memuat hubungan variabel $e$-WOM terhadap variabel niat berkunjung kembali wisatawan yang dimediasi oleh variabel citra destinasi. Penelitian ini bertujuan untuk: 1) menjelaskan pengaruh $e$-WOM terhadap niat niat berkunjung kembali wisatawan; 2) menjelaskan pengaruh $e$-WOM terhadap citra destinasi; 3) menjelaskan pengaruh citra destinasi terhadap niat berkunjung kembali wisatawan; dan 4) menjelaskan peran citra destinasi dalam memediasi pengaruh $e$-WOM terhadap niat berkunjung kembali wisatawan.

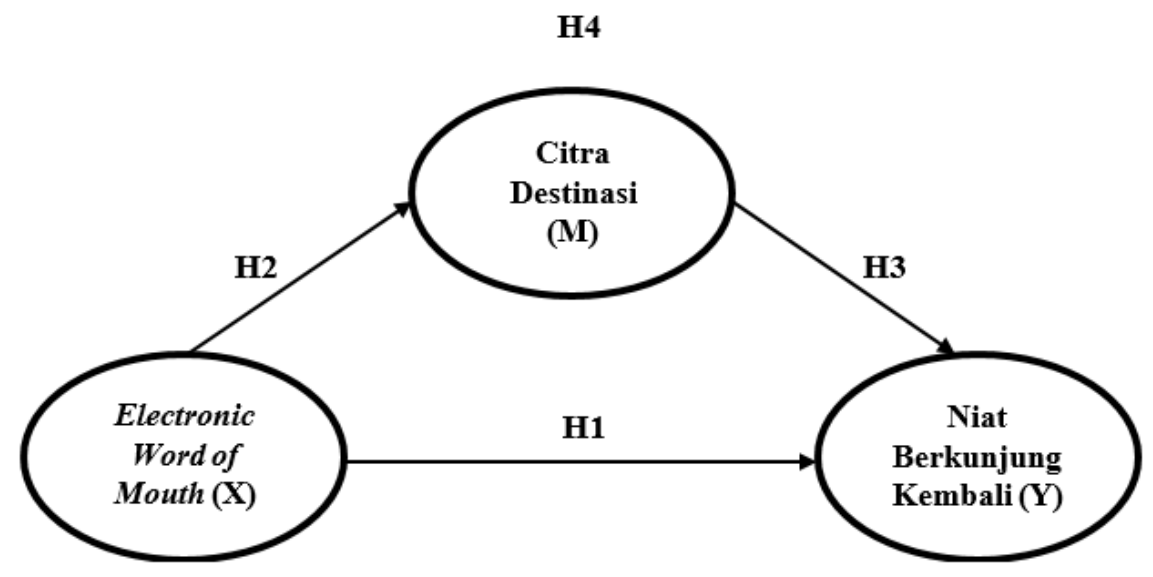

\section{Gambar 1. Kerangka Konseptual}

Sumber: $\quad$ Abubakar et al. (2017); Chew dan Jahari (2014); Dongfeng (2013); Doosti et al. (2016); Jalilvand et al. (2012); Jalilvand dan Heidary (2017); Kim dan Lee (2015); Loi et al. (2017); Mulyati dkk. (2018); Allameh et al. (2015); Prayogo dan Kusumawardhani (2016); Setiawan dkk. (2014); Suwarduki dkk. (2016); Tan (2017).

Secara umum telah dijelaskan pengertian dari variabel-variabel penelitian. Suatu fenomena/gejala dapat diklasifikasikan dalam bentuk variabel-variabel penelitian yang kemudian dipelajari dan ditarik kesimpulannya (Sugiyono, 2017:66). Fenomena mengenai peran komunikasi elektronik, citra destinasi dan niat berkunjung kembali wisatawan pastinya terjadi di beberapa destinasi wisata, termasuk di obyek wisata Taman Edelweis Bali yang viral di media sosial beberapa waktu yang lalu.

Obyek wisata Taman Edelweis Bali merupakan obyek wisata baru yang terletak di Banjar Dinas Temukus, Desa Besakih, Kecamatan Rendang, Kabupaten Karangasem. Mulai dibangun sejak 20 Juni 2018 oleh masyarakat desa, daya tarik wisata ini menawarkan keindahan panorama alam dengan hamparan bunga dan bangunan kayu yang ditata dengan rapi. Obyek wisata ini menjadi favorit kunjungan wisata bagi sebagian orang yang ingin merasakan spot baru dan lokasi foto yang instagramable. Sebagian besar wisatawan mengetahui destinasi wisata ini melalui penyampaian dari mulut ke mulut dan informasi yang diunggah di media sosial, baik berupa tulisan, foto, ataupun informasi event di obyek wisata ini. Belakangan, destinasi wisata ini ramai dikunjungi wisatawan domestik dan 
mancanegara. Terbukti dari meningkatnya kunjungan wisatawan ke obyek wisata ini. Berikut data kunjungan wisatawan ke obyek wisata Taman Edelweis Bali.

Tabel 1.

Data Kunjungan Wisatawan ke Taman Edelweis Bali Periode September Desember 2018 dan Februari - Agustus 2019

\begin{tabular}{cccc}
\hline Bulan & Wisatawan Lokal & $\begin{array}{l}\text { Wisatawan } \\
\text { Nusantara }\end{array}$ & $\begin{array}{c}\text { Wisatawan } \\
\text { Mancanegara }\end{array}$ \\
\hline
\end{tabular}

Tahun 2018 :

$\begin{array}{lccc}\text { September } & 4.593 & 186 & 55 \\ \text { Oktober } & 3.612 & 352 & 41 \\ \text { Nopember } & 12.209 & 732 & 57 \\ \text { Desember } & 38.512 & 4.271 & 55 \\ \text { tal } & \mathbf{5 8 . 9 2 6} & \mathbf{5 . 5 4 1} & \mathbf{2 0 8}\end{array}$

Tahun 2019 :

$\begin{array}{lccc}\text { Februari } & 9.018 & 22 & 32 \\ \text { Maret } & 8.210 & 15 & 0 \\ \text { April } & 5.923 & 3 & 5 \\ \text { Mei } & 3.061 & 35 & 0 \\ \text { Juni } & 7.791 & 74 & 38 \\ \text { Juli } & 7.191 & 148 & 31 \\ \text { Agustus } & 4.638 & 86 & 43 \\ \text { al } & \mathbf{4 5 . 8 3 2} & \mathbf{3 8 3} & \mathbf{1 4 9}\end{array}$

Dari Tabel 1. dapat dilihat jumlah kunjungan wisatawan ke obyek wisata Taman Edelweis Bali yang meningkat diawal pendiriannya dan sedikit mengalami penurunan di tahun 2019. Pada bulan September - Desember 2018 terjadi peningkatan yang signifikan, tetapi pada bulan Februari - Agustus 2019 kunjungan wisatawan berfluktuasi. Jenis wisatawannya pun bervariasi, mulai dari wisatawan lokal (yang mendominasi), wisatawan Nusantara, dan wisatawan mancanegara. Peningkatan tersebut tidak terlepas dari peran komunikasi yang dilakukan secara elektronik/online dan persepsi wisatawan tentang destinasi wisata Taman Edelweis Bali.

Peningkatan kunjungan wisatawan disebabkan oleh keunggulan dan keunikan yang dimiliki oleh obyek wisata ini. Sehingga menambah niat calon wisatawan untuk berkunjung dan kembali berwisata di obyek wisata Taman Edelweis Bali. Selain itu, informasi yang disebar melalui media sosial juga sangat mempengaruhi niat wisatawan untuk melakukan kunjungan kembali. Dari pernyataan tersebut dapat ditarik suatu kesimpulan sementara bahwa $e$-WOM berpengaruh positif dan signifikan terhadap niat berkunjung kembali wisatawan. Kesimpulan sementara tersebut didasarkan pada studi empiris sebelumnya yang dilakukan oleh Abubakar et al. (2017); Doosti et al. (2016); Prayogo dan Kusumawardhani (2016); Suwarduki dkk. (2016); dan Mulyati dkk. (2018) yang menyatakan bahwa $e-W O M$ berpengaruh positif signifikan terhadap niat berkunjung kembali wisatawan. Berdasarkan kajian empiris tersebut dapat dibangun hipotesis sebagai berikut. $\mathrm{H}_{1}$ : E-WOM berpengaruh positif dan signifikan terhadap niat berkunjung kembali. 
Peningkatan kunjungan wisatawan yang signifikan di awal tahun pendiriannya merupakan hasil yang baik bagi obyek wisata Taman Edelweis Bali, karena semakin meningkatkan brand destinasi wisata ini. Namun, peningkatan kunjungan wisatawan harus diimbangi dengan kualitas layanan yang baik pula, karena menentukan citra dari destinasi wisata. Meskipun fasilitas penunjang berwisata yang diberikan masih kurang memuaskan, obyek wisata Taman Edelweis Bali tidak pernah sepi pengunjung. Wisatawan selalu datang untuk berwisata di obyek wisata ini. Setiap musim liburan, Taman Edelweis Bali selalu dipadati wisatawan yang berkunjung. Opsi kunjungan wisata ke destinasi Taman Edelweis Bali muncul karena informasi yang disebar melalui media sosial, dan mempengaruhi citra destinasi wisata Taman Edelweis Bali. Berdasarkan pernyataan tersebut dapat ditarik kesimpulan sementara bahwa $e$-WOM berpengaruh terhadap citra destinasi dan diperkuat oleh penelitian sebelumnya yang dilakukan oleh Setiawan dkk. (2014); Jalilvand et al. (2017); Doosti et al. (2016); Suwarduki dkk. (2016); dan Mulyati dkk. (2018) yang menjelaskan bahwa $e$-WOM berpengaruh positif signifikan terhadap citra destinasi. Berdasarkan hasil penelitian empiris tersebut, dapat ditarik hipotesis sebagai berikut.

$\mathrm{H}_{2}$ : E-WOM berpengaruh positif dan signifikan terhadap Citra Destinasi.

Citra destinasi ditentukan oleh penilaian yang diberikan wisatawan, ataupun bagaimana organisasi bisnis (obyek wisata) mengatur sistem yang ada di perusahaan tersebut. Chi dan Qu (2008) mengemukakan bahwa terdapat sembilan variabel pengukuran dalam citra destinasi. Meliputi lingkungan, wisata alam, acara dan hiburan, atraksi bersejarah/budaya, infrastruktur, aksesibilitas, relaksasi, kegiatan luar ruangan, serta harga dan nilai. Keterkaitan satu dengan yang lain akan membentuk persepsi wisatawan dalam memberikan penilaian atas apa yang sudah didapatkan. Persepsi dan penilaian yang baik wisatawan tentang obyek wisata Taman Edelweis Bali akan meningkatkan niat wisatawan untuk mengunjungi kembali. Seperti yang diungkapkan oleh Allameh et al. (2015) yang menjelaskan bahwa citra destinasi berpengaruh positif signifikan terhadap niat berkunjung kembali. Kemudian Loi et al. (2017); Dongfeng (2013); Suwarduki dkk. (2016); dan Mulyati dkk. (2018) yang masing-masing menjelaskan adanya hubungan positif signifikan antara citra destinasi dengan niat berkunjung kembali wisatawan. Dari hasil penelitian-penelitian tersebut, dapat ditarik kesimpulan sebagai berikut. $\mathrm{H}_{3}$ : Citra destinasi berpengaruh positif signifikan terhadap niat berkunjung kembali.

Beerli dan Martín (2004) setuju bahwa WOM dianggap sebagai saluran komunikasi yang paling dapat dipercaya dan jujur, yang juga secara signifikan mempengaruhi citra destinasi. Tetapi, konsumen juga dapat memberikan pernyataan secara aktual mengenai produk atau perusahaan melalui pernyataan positif atau negatif pada situs internet perusahaan atau mass network yang memungkinkan diketahui oleh banyak orang sebagai akibat dari $e$-WOM tersebut (Shahrinaz et al., 2016).

Hasil prasurvei yang sudah dilakukan kepada 30 orang responden menunjukkan bahwa $e-W O M$ memiliki peran penting dalam pemasaran di era digital saat ini. Komunikasi secara elektronik (e-WOM) mampu membentuk opini publik dan menyangkut tentang citra destinasi serta niat konsumen untuk melakukan transaksi atau memutuskan pilihan. Niat berkunjung kembali wisatawan 
ditentukan oleh informasi yang didapat dan penggambaran atas informasi tersebut. Lee (2009) dan Phau et al. (2010) dalam Jalilvand et al. (2012) menunjukkan bahwa citra destinasi yang dirasakan adalah prediktor utama dari niat pilihan destinasi. Di dunia serba canggih saat ini, seluruh konten dapat dimuat dalam satu rubrik atau gambar, yang berfungsi untuk menyosialisasikan dan menarik minat konsumen/wisatawan. Citra destinasi mampu menguatkan hubungan antara $e$ WOM dengan niat berkunjung kembali wisatawan. Pernyataan tersebut sesuai dengan studi yang dilakukan oleh Jalilvand et al. (2012) dan Chew dan Jahari (2014). Maka dapat ditarik hipotesis penelitian sebagai berikut.

$\mathrm{H}_{4}$ : Citra destinasi mampu memediasi secara signifikan pengaruh $e$-WOM terhadap niat berkunjung kembali.

\section{METODE PENELITIAN}

Penelitian ini merupakan penelitian asosiatif, yang bermaksud menggambarkan dan menguji hipotesis hubungan dua variabel atau lebih (Sugiyono, 2017:20). Pendekatan yang digunakan dalam penelitian ini adalah pendekatan kuantitatif, yang dilandaskan pada filsafat positivisme untuk meneliti suatu sampel pada populasi (Sugiyono, 2017:23). Penelitian ini dilakukan di obyek wisata Taman Edelweis Bali yang terletak di Banjar Temukus, Desa Besakih, Kecamatan Rendang, Kabupaten Karangasem, Bali, Indonesia. Adapun variabelvariabel dalam penelitian ini adalah $e$-WOM sebagai variabel eksogen, citra destinasi sebagai variabel mediasi dan niat berkunjung kembali wisatawan sebagai variabel endogen. Data dalam penelitian ini dikumpulkan melalui instrumen penelitian berupa kuesioner. Metode pengumpulan data berupa penyebaran kuesioner yang secara offline dengan langsung ke lapangan dan online dengan menggunakan Google Form. Pernyataan-pernyataan dalam kuesioner diukur menggunakan skala Likert dari skala 1 sampai dengan skala 5.

Populasi dalam penelitian ini adalah seluruh wisatawan yang sudah pernah berkunjung ke obyek wisata Taman Edelweis Bali. Kemudian sampel yang digunakan adalah beberapa wisatawan domestik yang sudah pernah berkunjung ke obyek wisata Taman Edelweis Bali. Metode penentuan sampel menggunakan metode nonprobability sampling dengan teknik purposive sampling. Jumlah indikator penelitian sebanyak 16 indikator dan responden penelitian sebanyak 128 responden. Kriteria sampel antara lain merupakan warga negara Indonesia, sudah berumur 17 tahun ke atas, dan sudah pernah berkunjung ke obyek wisata Taman Edelweis Bali.

Teknik analisis data yang digunakan adalah analisis statistik deskriptif dan analisis statistik inferensial. Analisis statistik inferensial meliputi analisis jalur (path analysis) dan uji sobel. Analisis jalur (path analysis) merupakan perluasan penerapan analisis regresi linear berganda untuk memprediksi hubungan kausalitas antarvariabel (model kausal) yang telah ditetapkan sebelumnya berdasarkan teori Utama (2016:159). Uji Sobel dilakukan untuk menguji peran mediasi yang diberikan oleh variabel citra destinasi terhadap $e$-WOM dengan niat berkunjung kembali wisatawan. Maka pengujian signifikansi variabel mediasi dalam model dapat diperiksa dari hasil uji pengaruh tidak langsung. 


\section{HASIL DAN PEMBAHASAN}

Responden yang diteliti berjumlah 128 orang yang merupakan wisatawan domestik, telah berusia 17 tahun ke atas dan pernah berkunjung ke obyek wisata Taman Edelweis Bali. Responden penelitian dikelompokkan berdasarkan jenis kelamin, usia, dan pekerjaan. Berikut tabel karakteristik responden penelitian.

Tabel 2.

Karakteristik Demografi Responden

\begin{tabular}{|c|c|c|}
\hline Klasifikasi & Jumlah (orang) & Persentase (\%) \\
\hline \multicolumn{3}{|l|}{ Jenis Kelamin } \\
\hline Laki-Laki & 62 & 48 \\
\hline Perempuan & 66 & 52 \\
\hline Total & 128 & 100 \\
\hline \multicolumn{3}{|l|}{ Umur } \\
\hline $17-25$ tahun & 82 & 64 \\
\hline $26-35$ tahun & 32 & 25 \\
\hline $36-45$ tahun & 6 & 5 \\
\hline $46-55$ tahun & 8 & 6 \\
\hline$\geq 56$ tahun & 0 & 0 \\
\hline Total & 128 & 100 \\
\hline \multicolumn{3}{|l|}{ Pekerjaan } \\
\hline PNS/ASN & 9 & 7 \\
\hline Pegawai Swasta & 34 & 27 \\
\hline Wiraswasta & 13 & 10 \\
\hline Pelajar/Mahasiswa & 53 & 41 \\
\hline Ibu Rumah Tangga & 7 & 6 \\
\hline Lainnya & 12 & 9 \\
\hline Total & 128 & 100 \\
\hline
\end{tabular}

Sumber: Data primer diolah, 2019

Hasil tersebut memberikan gambaran bahwa wisatawan perempuan lebih dominan dibandingkan laki-laki, walaupun hanya berbeda sedikit angka. Dapat dibuktikan dengan persentase sebesar 52 persen (66 orang) perempuan dan 48 persen (62 orang) laki-laki. Kemudian responden yang berusia 17 hingga 25 tahun, yang merupakan fase remaja akhir (Depkes RI, 2009) lebih dominan melakukan kunjungan ke obyek wisata Taman Edelweis Bali dengan persentase 64 persen. Dan wisatawan yang berprofesi sebagai pelajar dan mahasiswa lebih dominan melakukan kunjungan. Itu dibuktikan dengan persentase sebesar 41 persen.

Indikator di masing-masing variabel yang tertuang dalam kuesioner penelitian sebelumnya telah diuji validitas dan reliabilitasnya. Hasil analisis uji menunjukkan bahwa keseluruhan pertanyaan kuesioner telah memenuhi standar uji validitas > 0,3 dan standar uji reliabilitas > 0,6 (Kuncoro, 2013:183). Itu menunjukkan bahwa kuesioner penelitian memang meneliti apa yang seharusnya diteliti (Kuncoro, 2013:172) dan tepat pada sasaran, sesuai dengan objek penelitian.

Analisis data responden menggunakan analisis statistik deskriptif dan statistik inferensial. Berikut adalah deskripsi penilaian responden terhadap variabel $e-W O M$, citra destinasi, dan niat berkunjung kembali. 
Tabel 3.

Deskripsi Penilaian Responden terhadap E-WOM

\begin{tabular}{|c|c|c|c|c|c|c|c|c|}
\hline \multirow{2}{*}{ No } & \multirow{2}{*}{ Pernyataan } & \multicolumn{5}{|c|}{ Jawaban (\%) } & \multirow{2}{*}{$\begin{array}{l}\text { Rata- } \\
\text { Rata }\end{array}$} & \multirow{2}{*}{ Keterangan } \\
\hline & & STS & TS & $\mathbf{N}$ & $\mathbf{S}$ & SS & & \\
\hline 1. & $\begin{array}{l}\text { Memberikan informasi } \\
\text { yang jelas }\end{array}$ & 0 & 1 & 6 & 67 & 54 & 4,35 & Sangat Baik \\
\hline 2. & $\begin{array}{l}\text { Mendapatkan } \\
\text { wawasan/pengetahuan }\end{array}$ & 0 & 1 & 19 & 71 & 37 & 4,12 & Baik \\
\hline 3. & $\begin{array}{l}\text { Mendapatkan jawaban } \\
\text { ketika mencari informasi }\end{array}$ & 0 & 1 & 12 & 74 & 41 & 4,21 & Sangat Baik \\
\hline 4. & $\begin{array}{l}\text { Konsisten dan handal } \\
\text { Rata-rata va }\end{array}$ & $\begin{array}{c}0 \\
\text { abel } e\end{array}$ & $\begin{array}{c}2 \\
\text { VOM }\end{array}$ & 21 & 72 & 33 & $\begin{array}{l}4,06 \\
\mathbf{4 , 1 8}\end{array}$ & $\begin{array}{l}\text { Baik } \\
\text { Baik }\end{array}$ \\
\hline
\end{tabular}

Sumber: Data primer diolah, 2019

Tabel 3. menunjukkan bahwa rata-rata keseluruhan penilaian responden mengenai variabel $e-W O M$ adalah sebesar 4,18 dan masuk dalam kategori baik. Secara keseluruhan jawaban responden merepresentasikan bahwa media komunikasi elektronik ( $e$-WOM) mampu memberikan informasi yang jelas terkait obyek wisata Taman Edelweis Bali dan menarik niat wisatawan untuk berkunjung kembali. Berikut adalah hasil penilaian responden terhadap variabel citra destinasi.

Tabel 4.

Deskripsi Penilaian Responden terhadap Citra Destinasi

\begin{tabular}{|c|c|c|c|c|c|c|c|c|}
\hline \multirow{2}{*}{ No } & \multirow{2}{*}{ Pernyataan } & \multicolumn{5}{|c|}{ Jawaban (\%) } & \multirow{2}{*}{$\begin{array}{l}\text { Rata- } \\
\text { Rata }\end{array}$} & \multirow{2}{*}{ Keterangan } \\
\hline & & STS & $\mathrm{TS}$ & $\mathrm{N}$ & $\mathrm{S}$ & SS & & \\
\hline 1. & $\begin{array}{l}\text { Kondisi lingkungan yang } \\
\text { nyaman }\end{array}$ & 0 & 1 & 21 & 64 & 42 & 4,14 & Baik \\
\hline 2. & $\begin{array}{l}\text { Pemandangan alam yang } \\
\text { indah }\end{array}$ & 0 & 0 & 10 & 61 & 57 & 4,36 & Sangat Baik \\
\hline 3. & $\begin{array}{l}\text { Memberikan ragam } \\
\text { hiburan }\end{array}$ & 0 & 7 & 44 & 58 & 19 & 3,69 & Baik \\
\hline 4. & $\begin{array}{l}\text { Fasilitas yang disediakan } \\
\text { memadai. }\end{array}$ & 1 & 9 & 44 & 59 & 15 & 3,6 & Baik \\
\hline 5. & $\begin{array}{l}\text { Akses yang mudah } \\
\text { dijangkau }\end{array}$ & 1 & 10 & 40 & 64 & 13 & 3,6 & Baik \\
\hline 6. & Dapat merelaksasikan diri & 0 & 0 & 15 & 70 & 43 & 4,21 & Sangat Baik \\
\hline 7. & $\begin{array}{l}\text { Dapat melakukan berbagai } \\
\text { aktivitas }\end{array}$ & 0 & 7 & 35 & 65 & 21 & 3,78 & Baik \\
\hline 8. & $\begin{array}{l}\text { Sesuai dengan biaya yang } \\
\text { dikeluarkan. }\end{array}$ & 0 & 3 & 30 & 63 & 32 & 3,96 & Baik \\
\hline \multicolumn{7}{|c|}{ Rata-rata variabel citra destinasi } & 3,92 & Baik \\
\hline
\end{tabular}

Sumber: Data primer diolah, 2019

Hasil yang disajikan pada Tabel 4. menunjukkan rata-rata penilaian responden tentang variabel citra destinasi. Keseluruhan indikator penilaian citra destinasi memperoleh nilai rata - rata sebesar 3,92 dan masuk dalam kriteria nilai 3,40 - 4,19 yaitu baik. Hasil ini memberikan gambaran bahwa citra (image) obyek wisata Taman Edelweis Bali baik di mata pengunjung, sehingga wisatawan cenderung untuk melakukan kunjungan kembali. Selanjutnya adalah penilaian responden terhadap variabel niat berkunjung kembali. 
Tabel 5.

Deskripsi Penilaian Responden terhadap Niat Berkunjung Kembali

\begin{tabular}{|c|c|c|c|c|c|c|c|c|}
\hline \multirow{2}{*}{ No } & \multirow{2}{*}{ Pernyataan } & \multicolumn{5}{|c|}{ Jawaban (\%) } & \multirow{2}{*}{$\begin{array}{l}\text { Rata- } \\
\text { Rata }\end{array}$} & \multirow{2}{*}{ Keterangan } \\
\hline & & STS & TS & $\mathrm{N}$ & $\mathrm{S}$ & SS & & \\
\hline 1. & $\begin{array}{l}\text { Berniat mengunjungi } \\
\text { dalam waktu dekat }\end{array}$ & 1 & 5 & 38 & 65 & 20 & 3,78 & Tinggi \\
\hline 2. & $\begin{array}{l}\text { Berencana mengunjungi } \\
\text { tahun depan }\end{array}$ & 2 & 7 & 43 & 64 & 12 & 3,6 & Tinggi \\
\hline 3. & Akan terus mengunjungi & 5 & 12 & 53 & 47 & 11 & 3,36 & Sedang \\
\hline 4. & $\begin{array}{l}\text { Merekomendasikan } \\
\text { wisatawan lain untuk } \\
\text { berkunjung kembali }\end{array}$ & 1 & 1 & 19 & 60 & 47 & 4,17 & Tinggi \\
\hline & Rata-rata variabel Nia & Berk & jung & Kem & & & 3,73 & Tinggi \\
\hline
\end{tabular}

Sumber: Data primer diolah, 2019

Tabel 5. menunjukkan bahwa rata-rata keseluruhan penilaian responden terhadap variabel niat berkunjung kembali sebesar 3,73 dan masuk dalam kategori tinggi. Berdasarkan hasil deskripsi penilaian wisatawan terhadap niat berkunjung kembali, indikator "Saya merekomendasikan wisatawan lain untuk berkunjung kembali ke obyek wisata Taman Edelweis Bali" mendapatkan rata-rata tertinggi dengan nilai sebesar 4,17. Hasil ini menunjukkan bahwa secara keseluruhan responden yang sudah pernah berkunjung merasa puas dan secara tidak langsung ikut mempromosikan obyek wisata Taman Edelweis Bali dengan mengajak sanak terdekat atau orang lain untuk melakukan kunjungan dan kembali berlibur ke obyek wisata Taman Edelweis Bali.

Setelah mengetahui hasil penilaian di masing-masing variabel, selanjutnya adalah mengetahui hubungan antarvariabel penelitian. Berikut merupakan hasil uji analisis jalur (path analysis) dan uji Sobel.

Tabel 6.

Hasil Analisis Jalur Persamaan Regresi 1

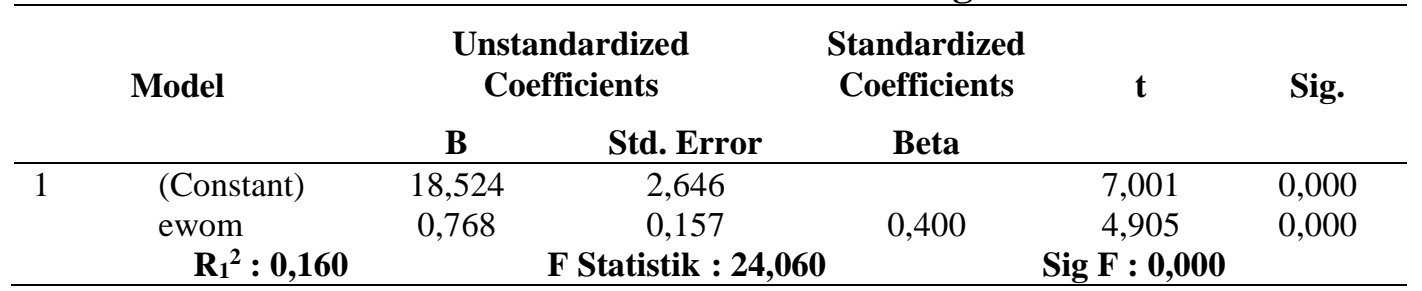

Sumber: Data primer diolah, 2019

Persamaan struktural yang dapat disusun berdasarkan Tabel 6. adalah sebagai berikut:

$$
\begin{aligned}
& M=\beta_{2} X+e_{1} \ldots \\
& M=0,400 X+e_{1}
\end{aligned}
$$

Berdasarkan Tabel 7. dapat disusun persamaan struktural sebagai berikut:

$$
\begin{aligned}
& Y=\beta_{1} X+\beta_{3} M+e_{2} \ldots \ldots . \\
& Y=0,169 X+0,605 M+e_{2}
\end{aligned}
$$


Besarnya pengaruh tidak langsung variabel $e$-WOM (X) terhadap niat berkunjung kembali (Y) dengan citra destinasi sebagai variabel mediasi (M) dapat dirumuskan dengan formula berikut ini :

indirect effect $=\beta_{2} \times \beta_{3}$

$$
\begin{aligned}
& =0.400 \times 0,605 \\
& =0,242
\end{aligned}
$$

Tabel 7.

\begin{tabular}{|c|c|c|c|c|c|c|}
\hline & \multirow[t]{2}{*}{ Model } & \multicolumn{2}{|c|}{ Unstandardized Coefficients } & \multirow{2}{*}{$\begin{array}{c}\text { Standardized } \\
\text { Coefficients } \\
\text { Beta } \\
\end{array}$} & \multirow[t]{2}{*}{$\mathbf{t}$} & \multirow[t]{2}{*}{ Sig. } \\
\hline & & B & Std. Error & & & \\
\hline \multirow[t]{4}{*}{1} & (Constant) & 0,609 & 1,448 & & 0,421 & 0,675 \\
\hline & ewom & 0,190 & 0,079 & 0,169 & 2,398 & 0,018 \\
\hline & citra & 0,355 & 0,041 & 0,605 & 8,570 & 0,000 \\
\hline & $R_{2}^{2}: 0,477$ & \multicolumn{2}{|c|}{ F Statistik : 56,963} & \multicolumn{3}{|c|}{ Sig F : 0,000} \\
\hline
\end{tabular}

Hasil Analisis Jalur Persamaan Regresi 2

Sumber: Data primer diolah, 2019

Langkah selanjutnya adalah menentukan pengaruh total variabel $e$-WOM terhadap niat berkunjung kembali yang dimediasi oleh citra destinasi.

$$
\begin{aligned}
\text { total effect } & =\beta_{1}+\left(\beta_{2}\right) \times\left(\beta_{3}\right) \ldots \ldots \ldots \ldots \\
& =0,169+(0,400 \times 0,605) \\
& =0,411
\end{aligned}
$$

Berdasarkan model substruktur 1 dan substruktur 2, maka dapat disusun model diagram jalur akhir. Sebelum menyusun model diagram jalur akhir, terlebih dahulu dihitung nilai standar error sebagai berikut :

$$
\begin{aligned}
& \mathrm{Pe}_{\mathrm{i}}=\sqrt{1-\mathrm{R}_{\mathrm{i}}{ }^{2}} \ldots \ldots \ldots \ldots \ldots \ldots \ldots \ldots \ldots \ldots \ldots \ldots \ldots \\
& \mathrm{Pe}_{1}=\sqrt{1-R_{1}^{2}}=\sqrt{1-0,160}=0,916 \\
& \mathrm{Pe}_{2}=\sqrt{1-R_{2}{ }^{2}}=\sqrt{1-0,477}=0,723
\end{aligned}
$$

Berikut perhitungan pengaruh error (Pei), didapatkan hasil pengaruh error $\left(\mathrm{Pe}_{1}\right)$ sebesar 0,916 dan pengaruh error $\left(\mathrm{Pe}_{2}\right)$ sebesar 0,723. Hasil koefisien determinasi total adalah sebagai berikut:

$$
\begin{aligned}
\mathrm{R}^{2}{ }_{\mathrm{m}} & =1-\left(\mathrm{Pe}_{1}\right)^{2}\left(\mathrm{Pe}_{2}\right)^{2} \ldots \ldots \\
& =1-(0,916)^{2}(0,723)^{2} \\
& =1-(0,839)(0.522) \\
& =1-0,437 \\
& =0,563
\end{aligned}
$$

Nilai determinasi total sebesar 0,563 mempunyai arti bahwa sebesar 56,3 persen niat berkunjung kembali wisatawan dipengaruhi oleh $e-W O M$ dan citra destinasi, sedangkan sisanya sebesar 43,7 persen dijelaskan oleh faktor lain yang tidak dimasukkan ke dalam model.

Berdasarkan hasil analisis pengaruh $e$-WOM terhadap niat berkunjung kembali diperoleh nilai Sig. $t$ sebesar 0,018 dengan nilai koefisien beta 0,169 . Nilai Sig. t 0,018<0,05 mengindikasikan bahwa $\mathrm{H}_{0}$ ditolak dan $\mathrm{H}_{1}$ diterima. Hasil ini 
mempunyai arti bahwa $e$-WOM berpengaruh positif dan signifikan terhadap niat berkunjung kembali.

Kemudian pengaruh $e$-WOM terhadap citra destinasi memperoleh nilai Sig. t sebesar 0,000 dengan nilai koefisien beta 0,400. Nilai Sig. t 0,000 $<0,05$ mengindikasikan bahwa $\mathrm{H}_{0}$ ditolak dan $\mathrm{H}_{1}$ diterima. Hasil ini mempunyai arti bahwa $e$-WOM berpengaruh positif dan signifikan terhadap citra destinasi.

Pengaruh citra destinasi terhadap niat berkunjung kembali diperoleh nilai Sig. $\mathrm{t}$ sebesar 0,000 dengan nilai koefisien beta 0,605. Nilai Sig. t 0,000<0,05 mengindikasikan bahwa $\mathrm{H}_{0}$ ditolak dan $\mathrm{H}_{1}$ diterima. Hasil ini mempunyai arti bahwa citra destinasi berpengaruh positif dan signifikan terhadap niat berkunjung kembali.

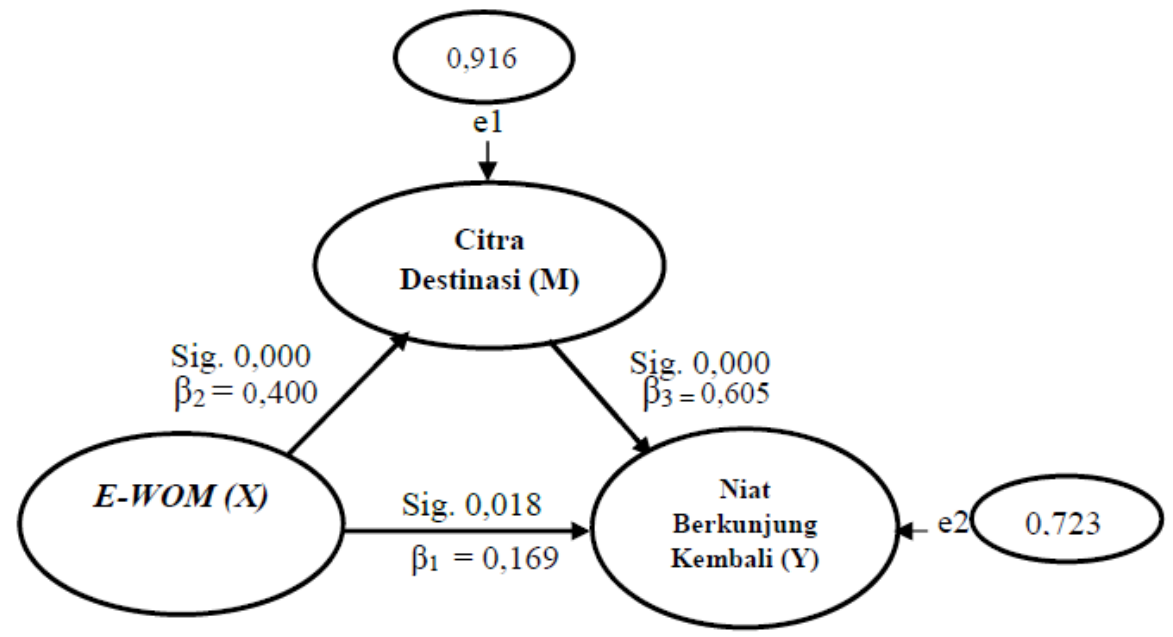

\section{Gambar 2. Diagram Koefisien Jalur E-WOM terhadap Niat Berkunjung Kembali melalui Citra Destinasi}

Sumber: Data primer diolah, 2019

Berdasarkan diagram jalur pada Gambar 2, maka dapat dihitung besarnya pengaruh langsung dan pengaruh tidak langsung serta pengaruh total antar variabel. Perhitungan pengaruh antar variabel dirangkum dalam Tabel 8. sebagai berikut

Tabel 8.

Pengaruh Langsung, Pengaruh Tidak Langsung dan Pengaruh Total $E-W O M(X)$, Citra Destinasi (M), dan Niat Berkunjung Kembali (Y)

\begin{tabular}{lccc}
\multicolumn{1}{c}{$\begin{array}{c}\text { Pengaruh } \\
\text { Variabel }\end{array}$} & $\begin{array}{c}\text { Pengaruh } \\
\text { Langsung }\end{array}$ & $\begin{array}{c}\text { Pengaruh Tidak Langsung } \\
\text { Melalui Citra Destinasi } \\
(\mathbf{M})=(\boldsymbol{\beta 2} \mathbf{x} \boldsymbol{\beta 3})\end{array}$ & $\begin{array}{c}\text { Pengaruh } \\
\text { Total }\end{array}$ \\
\hline $\begin{array}{l}E-W O M \rightarrow \text { Niat } \\
\text { Berkunjung }\end{array}$ & 0,169 & 0,242 & 0,411 \\
Kembali & & \\
$\begin{array}{l}E \text {-WOM } \rightarrow \text { Citra } \\
\text { Destinasi }\end{array}$ & 0,400 & - & 0,400 \\
$\begin{array}{l}\text { Citra Destinasi } \rightarrow \\
\text { Niat Berkunjung } \\
\text { Kembali }\end{array}$ & 0,605 & - & \\
\hline Sumber: Data primer diolah, 2019 & & \\
\hline
\end{tabular}


Setelah mengetahui hasil analisis jalur, selanjutnya adalah menganalisis variabel mediasi menggunakan uji Sobel. Uji sobel merupakan alat analisis untuk menguji signifikansi dari hubungan tidak langsung antara variabel independen dengan variabel dependen yang dimediasi oleh variabel mediator. Jika $\mathrm{Z}$ hitung > 1,96 dan taraf nyata alpha 0,05 maka citra destinasi merupakan variabel mediasi. Penghitungan variabel mediasi menggunakan statistik uji.

Uji sobel dihitung dengan rumus dibawah ini:

$$
\begin{aligned}
& Z=\frac{\mathrm{ab}}{\sqrt{\mathrm{b}^{2} s_{a}^{2}+a^{2} s_{b}^{2}+s_{a}^{2} s_{b}^{2}}} \\
& \operatorname{Sig}=(1-\operatorname{NORMDIST}(Z))+2)) \\
& \text { Keterangan: } \\
& \text { a }=0,768 \\
& \mathrm{~s}_{\mathrm{a}}=0,157 \\
& \mathrm{~b}=0,355 \\
& \mathrm{sb}_{\mathrm{b}}=0,041 \\
& \begin{array}{c}
Z=\frac{0,768(0,355)}{\sqrt{0,355^{2}\left(0,157^{2}\right)+0,768^{2}\left(0,041^{2}\right)+0,157^{2}\left(0,041^{2}\right)}} \\
Z=\frac{0,27264}{\sqrt{0,0031+0,0009+0,00004}} \\
Z=\frac{0,27264}{0,06356} \\
Z=4,289
\end{array}
\end{aligned}
$$

Hasil pengujian uji Sobel didapatkan $\mathrm{Z}$ hitung sebesar 4,289 > 1,96 dengan tingkat signifikan sebesar $0,000<0.05$ yang berarti $\mathrm{H}_{0}$ ditolak dan $\mathrm{H}_{1}$ diterima, dengan demikian citra destinasi merupakan variabel pemediasi hubungan antara variabel $e-W O M$ terhadap variabel niat berkunjung kembali wisatawan di obyek wisata Taman Edelweis Bali.

Berdasarkan hasil analisis hipotesis pertama yaitu pengaruh $e$-WOM terhadap niat berkunjung kembali, disimpulkan bahwa variabel $e$-WOM berpengaruh positif signifikan terhadap variabel niat berkunjung kembali wisatawan di obyek wisata Taman Edelweis Bali. Hasil tersebut memberikan makna bahwasannya semakin jelas informasi yang disebar, sehingga mampu memberikan wawasan dan pengetahuan kepada para pengunjung dalam mencari informasi wisata Taman Edelweis Bali, maka tingkat kunjungan kembali wisatawan akan semakin tinggi. Hasil ini mengonfirmasi definisi perilaku konsumen menurut Sumarwan (2004:26) yang menyatakan bahwa semua kegiatan, tindakan, serta proses psikologis yang mendorong tindakan tersebut pada saat sebelum membeli, ketika membeli, menggunakan, menghabiskan produk dan jasa setelah melakukan hal-hal tersebut atau kegiatan mengevaluasi. Selain itu, hasil ini sesuai dengan penelitian yang dilakukan oleh Abubakar et al. (2017), Doosti et al. (2016), Prayogo dan Kusumawardhani (2016), Suwarduki dkk. (2016) dan Mulyati dkk. (2018) yang menyimpulkan bahwa $e-W O M$ berpengaruh positif signifikan terhadap niat berkunjung kembali wisatawan ke obyek wisata Taman Edelweis Bali. 
Hipotesis kedua bertujuan untuk menjelaskan pengaruh $e$-WOM terhadap citra destinasi obyek wisata Taman Edelweis Bali. Berdasarkan hasil analisis, dapat disimpulkan variabel $e$-WOM berpengaruh positif dan signifikan terhadap variabel citra destinasi obyek wisata Taman Edelweis Bali. Hasil ini memberikan arti bahwa penyebaran informasi yang dilakukan dari mulut ke mulut secara elektronik maupun online tentang obyek wisata Taman Edelweis Bali mampu meyakinkan wisatawan sehingga menimbulkan persepsi yang baik tentang obyek wisata Taman Edelweis Bali. Hasil penelitian ini mengonfirmasi pendapat Hennig-Thurau et al. (2004) yang menjelaskan $e$-WOM sebagai pernyataan positif atau negatif yang dibuat oleh pelanggan potensial, aktual, atau mantan pelanggan tentang suatu produk atau perusahaan yang dalam hal ini adalah obyek wisata Taman Edelweis Bali melalui internet. Fletcher et al. (2018:616) memperkuat pernyataan tersebut dengan mendefinisikan citra destinasi sebagai sebuah kesadaran individu tentang suatu tempat tujuan yang terdiri dari evaluasi kognitif dari pengalaman, pembelajaran, emosi dan persepsi. Hasil ini sesuai dengan studi empiris yang dilakukan oleh Setiawan (2014), Jalilvand et al. (2017), Doosti et al. (2016) menyatakan $e$-WOM berpengaruh positif signifikan terhadap citra destinasi. Begitupun Suwarduki dkk. (2016) dan Mulyati dkk. (2018) mengemukakan hal yang sama.

Hipotesis ketiga analisis pengaruh citra destinasi terhadap niat berkunjung kembali wisatawan di obyek wisata Taman Edelweis Bali. Berdasarkan hasil analisis didapatkan bahwa variabel citra destinasi berpengaruh positif dan signifikan terhadap variabel niat berkunjung kembali wisatawan di obyek wisata Taman Edelweis Bali. Hasil ini memberikan makna semakin baik persepsi wisatawan tentang obyek wisata Taman Edelweis Bali, maka niat berkunjung kembali wisatawan juga semakin tinggi. Hasil ini sejalan dengan pendapat Kotler (2000:165) yang menyatakan niat merupakan suatu dorongan, atau rangsangan internal yang kuat yang memotivasi tindakan dimana dorongan ini dipengaruhi oleh stimulus dan perasaan positif akan produk. Penelitian ini pun sesuai dengan studi yang dilakukan oleh Allameh et al. (2015); Loi et al. (2017); Dongfeng (2013) menyimpulkan bahwa faktor citra destinasi berpengaruh positif signifikan terhadap niat berkunjung kembali wisatawan. Hasil serupa juga ditemukan oleh penelitian yang dilakukan oleh Suwarduki dkk. (2016) dan Mulyati dkk. (2018) yang menunjukkan adanya pengaruh yang signifikan positif antara citra destinasi terhadap niat berkunjung wisatawan.

Hipotesis keempat yaitu menjelaskan peran citra destinasi dalam memediasi pengaruh $e$-WOM terhadap niat berkunjung kembali wisatawan, sebagai hipotesis keempat yang telah diuji dalam penelitian ini. Hasil uji pengaruh $e$-WOM terhadap niat berkunjung kembali wisatawan semula bernilai 0.169 , kemudian setelah adanya citra destinasi sebagai variabel mediasi, nilai pada pengaruh $e$-WOM terhadap niat berkunjung kembali meningkat menjadi 0,411.

Hasil tersebut menunjukkan bahwa citra destinasi mampu memediasi pengaruh $e-W O M$ terhadap niat berkunjung kembali secara parsial. Uji Sobel yang telah dilakukan memperkuat hasil tersebut dengan nilai koefisien $\mathrm{Z}$ yang diperoleh adalah 4,289 > 1,96, sehingga dapat dikatakan bahwa citra destinasi merupakan variabel pemediasi hubungan antara variabel $e$-WOM terhadap variabel niat 
berkunjung kembali secara signifikan. Hasil ini mengonfirmasi pendapat Weaver dan Lawton (2014:406) yang menyatakan citra (image) sebagai keseluruhan keyakinan, sikap dan kesan individu atau kelompok yang dipegang terhadap destinasi wisata atau aspek suatu destinasi dan merupakan faktor kritis yang mampu menarik atau mendorong wisatawan untuk meninggalkan destinasi wisata. Fletcher et al. (2018:616) turut memperkuat hasil penelitian ini dengan menjelaskan citra destinasi sebagai sebuah kesadaran individu tentang suatu tempat tujuan yang terdiri dari evaluasi kognitif dari pengalaman, pembelajaran, emosi dan persepsi. Temuan ini pun sesuai dengan penelitian yang dilakukan oleh Jalilvand et al. (2012) dan Chew \& Jahari (2014) yang menyatakan bahwa $e$-WOM berpengaruh signifikan terhadap citra destinasi yang pada akhirnya berdampak pada niat berkunjung wisatawan.

Hasil penelitian ini memperkaya kajian ilmu Manajemen khususnya pada bidang Manajemen Pemasaran yang berkaitan dengan perilaku konsumen sebagai keseluruhan kegiatan, tindakan, serta proses psikologis yang mendorong tindakan tersebut pada saat sebelum membeli, ketika membeli, menggunakan, menghabiskan produk dan jasa setelah melakukan hal-hal tersebut atau kegiatan mengevaluasi (Sumarwan, 2004:26). Pengembangan citra destinasi obyek wisata Taman Edelweis Bali harus didasarkan pada faktor-faktor pembentuk/indikator penilaian citra destinasi, agar mampu menarik niat wisatawan untuk melakukan kunjungan kembali. Pengelola obyek wisata Taman Edelweis Bali diharapkan lebih memperhatikan segala aspek yang menopang aktivitas berwisata pengunjung, seperti kebersihan obyek wisata, pemeliharaan, dan inovasi-inovasi yang mampu memuaskan wisatawan ketika berwisata, sehingga mampu menarik niat wisatawan untuk berkunjung kembali. Promosi wisata melalui platform digital-online terbukti sangat efektif dalam menyalurkan informasi wisata yang dimiliki. Selain itu, sinergi antara pengelola obyek wisata dan pemerintah penting dilakukan guna menjamin keberadaan obyek wisata Taman Edelweis Bali dengan cara memberikan dukungan secara moril, fisik maupun finansial kepada pengelola obyek wisata Taman Edelweis Bali dalam menjalankan aktivitas bisnis maupun setiap kali melaksanakan event wisata.

Terdapat keterbatasan dalam penelitian ini dimana hanya di obyek wisata Taman Edelweis Bali, sehingga hasil penelitian ini tidak dapat digeneralisir untuk obyek wisata yang lain dan dilakukan dalam titik waktu tertentu (cross section) sedangkan kondisi yang terjadi pada obyek wisata Taman Edelweis Bali sewaktuwaktu dapat berubah (dinamis). Maka dari itu penelitian ini penting untuk dilakukan kembali di masa mendatang.

\section{SIMPULAN}

Simpulan yang dapat diberikan berdasarkan pembahasan yang sudah dilakukan adalah: 1) $E$-WOM berpengaruh positif dan signifikan terhadap niat berkunjung kembali wisatawan ke obyek wisata Taman Edelweis Bali. Semakin baik penyampaian informasi yang dilakukan melalui media komunikasi elektronik maupun online maka semakin tinggi niat pengunjung untuk melakukan kunjungan kembali. 2) $E$-WOM berpengaruh positif dan signifikan terhadap citra destinasi 
obyek wisata Taman Edelweis Bali. Semakin baik informasi yang diberikan melalui media komunikasi elektronik maupun online dan mampu meyakinkan pengunjung, maka semakin baik pula citra obyek wisata Taman Edelweis Bali. 3) Citra destinasi berpengaruh positif dan signifikan terhadap niat berkunjung kembali wisatawan ke obyek wisata Taman Edelweis Bali. Semakin baik persepsi tentang citra destinasi obyek wisata Taman Edelweis Bali, maka semakin tinggi niat berkunjung kembali wisatawan. 4) Citra destinasi memediasi pengaruh antara $e$-WOM dengan niat berkunjung kembali wisatawan di obyek wisata Taman Edelweis Bali. Semakin baik $e-W O M$ yang diberikan, dengan penyampaian informasi yang jelas, mengedukasi, tanggap dan konsisten akan mampu menggugah niat seseorang untuk berkunjung kembali. Kemudian ditambah dengan image yang baik dari Taman Edelweis Bali, melalui pandangan dan penilaian wisatawan terhadap berbagai aspek yang mendukung citra destinasi obyek wisata, akan menambah niat wisatawan untuk mengunjungi kembali obyek wisata Taman Edelweis Bali.

Adapun saran-saran yang dapat diberikan adalah sebagai berikut: 1) Pengelola obyek wisata Taman Edelweis Bali harus memberikan informasi yang tepat agar wisatawan tertarik untuk melakukan kunjungan kembali. Informasi yang diberikan harus sesuai dengan apa yang ada di lapangan serta memberikan pengetahuan seputar daya tarik wisata Taman Edelweis Bali. Pembuatan website penting dilakukan untuk memudahkan semua pihak dalam mengakses informasi seputar event, promo, harga dan atraksi baru yang ada di obyek wisata Taman Edelweis Bali. 2) Pengelola obyek wisata Taman Edelweis Bali harus memperhatikan dan memperbaiki fasilitas penunjang yang ada, seperti toilet yang bersih, tempat sampah, kafe yang menyediakan berbagai menu makanan, spot foto yang aman dan menjamin keselamatan wisatawan yang berkunjung dan peringatan menjaga kebersihan. Akses menuju obyek wisata yang jelas dan mudah dijangkau akan sangat menentukan niat wisatawan untuk melakukan kunjungan kembali. Menyediakan ragam acara dan hiburan yang menarik akan menstimulus pengunjung untuk lebih meyakinkan kunjungannya kembali di kemudian hari. Pihak pengelola harus aktif memberikan inovasi baru, seperti penambahan spot foto baru, pengadaan souvenir, challenge maupun hal menarik lain yang mengundang niat wisatawan untuk melakukan kunjungan kembali. 3) Bagi peneliti selanjutnya diharapkan dapat meneliti topik penelitian yang lain seperti bauran pemasaran, kesadaran lingkungan, perceived price justice, destination attributes, travel constraints, environmental concern, ecotourism experience, kualitas acara dan sebagainya yang menarik untuk diteliti dan mendukung keberadaan obyek wisata Taman Edelweis Bali.

\section{REFERENSI}

Abubakar, A. M., Ilkan, M., Meshall Al-Tal, R., \& Eluwole, K. K. (2017). eWOM, revisit intention, destination trust and gender. Journal of Hospitality and Tourism Management, 31, 220-227. https://doi.org/10.1016/j.jhtm.2016.12.005

Allameh, S. M., Pool, J. K., Jaberi, A., Salehzadeh, R., \& Asadi, H. (2015). Article 
information : Factors influencing sport tourists' revisit intentions: the role and effect of destination image, perceived quality, perceived value and satisfaction. Asia Pacific Journal of Marketing and Logistics, 27(2). https://doi.org/10.1108/APJML-12-2013-0159

Baber, A., Thurasamy, R., Malik, M. I., Sadiq, B., Islam, S., \& Sajjad, M. (2016). Online word-of-mouth antecedents, attitude and intention-to-purchase electronic products in Pakistan. Telematics and Informatics, 33(2), 388-400. https://doi.org/10.1016/j.tele.2015.09.004

Badan Pengelola Obyek Wisata Taman Edelweis Bali. Data Bulanan Kunjungan Wisatawan Ke Obyek Wisata Taman Edelweis Bali. Maret. Taman Edelweis Bali, Rendang, Karangasem, Bali.

Beerli, A., \& Martín, J. D. (2004). Factors influencing destination image. Annals of Tourism Research, $31(3)$ $657-681$. https://doi.org/10.1016/j.annals.2004.01.010

Chew, E. Y. T., \& Jahari, S. A. (2014). Destination image as a mediator between perceived risks and revisit intention: A case of post-disaster Japan. Tourism Management, 40, 382-393. https://doi.org/10.1016/j.tourman.2013.07.008

Chi, C. G. Q., \& Qu, H. (2008). Examining the structural relationships of destination image, tourist satisfaction and destination loyalty: An integrated approach. Tourism Management, 29(4), 624-636. https://doi.org/10.1016/j.tourman.2007.06.007

Darmawan, R., \& Nurcaya, I. N. (2018). Membangun Niat Beli Iphone Melalui EWOM dan Brand Image. E-Jurnal Manajemen Unud, 7(9), 5168-5196. https://doi.org/10.24843/EJMUNUD.2018.v7.i09.p20 ISSN:

Dongfeng, L. (2013). Major sports events, destination image and intention to revisit from the foreign tourist's perspective. International Journal of Sports Marketing and Sponsorship, 14(3), 23-34. https://doi.org/10.1108/ijsms-1403-2013-b003

Doosti, S., Jalilvand, M. R., Asadi, A., Khazaei Pool, J., \& Mehrani Adl, P. (2016). Analyzing the influence of electronic word of mouth on visit intention: the mediating role of tourists' attitude and city image. International Journal of Tourism Cities, 2(2), 137-148. https://doi.org/10.1108/IJTC-12-2015-0031

Ferns, B. H., \& Walls, A. (2012). Enduring travel involvement, destination brand equity, and travelers' visit intentions: A structural model analysis. Journal of Destination Marketing and Management, 1(1-2), 27-35. https://doi.org/10.1016/j.jdmm.2012.07.002 
Fletcher, J., Fyall, A., Gilbert, D., \& Wanhill, S. (2018). Tourism : Principles and Practic (Sixth Edit). United Kingdom: Pearson.

Gruen, T. W., Osmonbekov, T., \& Czaplewski, A. J. (2006). eWOM: The impact of customer-to-customer online know-how exchange on customer value and loyalty. Journal of Business Research, 59(4), 449-456. https://doi.org/10.1016/j.jbusres.2005.10.004

Hennig-Thurau, T., Gwinner, K. P., Walsh, G., \& Gremler, D. D. (2004). Electronic word-of-mouth via consumer-opinion platforms: What motivates consumers to articulate themselves on the Internet? Journal of Interactive Marketing, 18(1), 38-52. https://doi.org/10.1002/dir.10073

Ishida, K., Slevitch, L., \& Siamionava, K. (2016). The Effects of Traditional and Electronic Word-of-Mouth on Destination Image: A Case of Vacation Tourists Visiting Branson, Missouri. Administrative Sciences, 6(4), 12. https://doi.org/10.3390/admsci6040012

Jalilvand, M. R., \& Heidary, A. (2017). Comparing face to face and electronic word-of-mouth in destination image formation: the case of Iran Mohammad. Information Technology \& People, 1-27. https://doi.org/10.1108/ITP-092016-0204 Permanent

Jalilvand, M. R., Samiei, N., Dini, B., \& Manzari, P. Y. (2012). Examining the structural relationships of electronic word of mouth, destination image, tourist attitude toward destination and travel intention: An integrated approach. Journal of Destination Marketing and Management, 1(1-2), 134-143. https://doi.org/10.1016/j.jdmm.2012.10.001

Kim, H., \& Lee, S. (2015). Impacts of city personality and image on revisit intention. International Journal of Tourism Cities, 1(1), 50-69. https://doi.org/10.1108/ijtc-08-2014-0004

Knoll, J. (2016). Advertising in social media: A review of empirical evidence. International Journal of Advertising, 35(2), 266-300. https://doi.org/10.1080/02650487.2015.1021898

Kotler, P. (2000). Manajemen Pemasaran di Indonesia. Analisis Perencanaan, Implementasi, dan Pengendalian. Dialih bahasakan oleh A.B Susanto. Jakarta: Salemba Empat.

Lee, T. H. (2009). A Structural model to examine how destination image, attitude, and motivation affect the future behavior of tourists. Leisure Sciences, 31(3), 215-236. https://doi.org/10.1080/01490400902837787

Loi, L. T. I., So, A. S. I., Lo, I. S., \& Fong, L. H. N. (2017). Does the quality of 
tourist shuttles influence revisit intention through destination image and satisfaction? The case of Macao. Journal of Hospitality and Tourism Management, 32, 115-123. https://doi.org/10.1016/j.jhtm.2017.06.002

Mulyati, Y., Haryeni, \& Masruri. (2018). Pengaruh Electronic Word Of Mouth Terhadap Citra Destinasi Serta Dampaknya Pada Minat Dan Keputusan Berkunjung Wisatawan Domestik Pada Destinasi Wisata Kota Bukittinggi. Jurnal Ekonomi \& Bisnis Dharma Andalas, 20(1), 168-187.

Phang, C. W., Zhang, C., \& Sutanto, J. (2013). The influence of user interaction and participation in social media on the consumption intention of niche products. Information and Management, 50(8), 661-672. https://doi.org/10.1016/j.im.2013.07.001

Phau, I., Shanka, T., \& Dhayan, N. (2010). Destination image and choice intention of university student travellers to Mauritius. International Journal of Contemporary Hospitality Management, 22(5), 758-764. https://doi.org/10.1108/09596111011053846

Prayogo, R. R., \& Kusumawardhani, A. (2016). Examining Relationships of Destination Image, Service Quality, e-WOM, and Revisit Intention to Sabang Island, Indonesia. Asia Pacific Management and Business Application, 5(2), 85-96. https://doi.org/10.21776/ub.apmba.2016.005.02.3

Priansa, D. J. (2017). Perilaku Konsumen Dalam Persaingan Bisnis Kontemporer. Bandung: Alfabeta.

Putri, N. P. A. K. K., \& Sukawati, T. G. R. (2019). Peran Citra Merek Memediasi Pengaruh E-Wom Terhadap Niat Beli (Studi Kasus pada Maskapai Penerbangan AirAsia di Kota Denpasar). 8(7), 4268-4297. https://doi.org/10.24843/EJMUNUD.2019.v08.i07.p10 ISSN

Rai Utama, I. G. B. (2016). Pemasaran Pariwisata. Yogyakarta: Penerbit Andi.

Seaton, A. V., \& Bennett, M. M. (1996). The Marketing of Tourism Products: Concepts, Issues and Cases. UK: International Thomson Business Press.

Setiawan, P. Y. (2014). The Effect of e-WOM on Destination Image, Satisfaction and Loyalty. International Journal of Business and Management Invention ISSN (Online, 3(1), 2319-8028.

Shahrinaz, I., Yacob, Y., Hummida, D., \& Abdul, A. (2016). Relationship and impact of e-WOM and brand image towards purchase intention of smartphone? Journal of Scientific Research and Development, 3(5), 117124. 
Stylos, N., Vassiliadis, C. A., Bellou, V., \& Andronikidis, A. (2016). Destination images, holistic images and personal normative beliefs: Predictors of intention to revisit a destination. Tourism Management, 53, 40-60. https://doi.org/10.1016/j.tourman.2015.09.006

Sugiyono. (2017). Metode Penelitian Binsis. Pendekatan Kuantitatif, Kualitatif, Kombinasi, dan $R \& D$. Bandung: Alfabeta.

Sumarwan, U. (2004). Perilaku Konsumen. Teori dan Penerapannya dalam Pemasaran. Bogor Selatan: Ghalia Indonesia.

Suprapti, N. W. S. (2010). Perilaku Konsumen. Pemahaman Dasar dan Aplikasinya dalam Strategi Pemasaran. Denpasar: Udayana University Press.

Suwarduki, P. R., Yulianto, E., \& Mawardi, M. K. (2016). Pengaruh Electronic Word Of Mouth Terhadap Citra Destinasi Serta Dampaknya Pada Minat Dan Keputusan Berkunjung (Survei pada Followers Aktif Akun Instagram Indtravel yang Telah Mengunjungi Destinasi Wisata di Indonesia). Jurnal Administrasi Bisnis S1 Universitas Brawijaya, 37(2), 1-10.

Tan, W. K. (2017). Repeat visitation: A study from the perspective of leisure constraint, tourist experience, destination images, and experiential familiarity. Journal of Destination Marketing and Management, 6(3), 233242. https://doi.org/10.1016/j.jdmm.2016.04.003

Torlak, O., Ozkara, B. Y., Tiltay, M. A., Cengiz, H., \& Dulger, M. F. (2014). The Effect of Electronic Word of Mouth on Brand Image and Purchase Intention: An Application Concerning Cell Phone Brands for Youth Consumers in Turkey. Journal of Marketing Development and Competitiveness, 8(2), 6168.

Utama, M. S. (2016). Aplikasi Analisis Kuantitatif. Denpasar: CV. Sastra Utama.

Weaver, D., \& Lawton, L. (2014). Tourism Management (Fifth Edit). Australia: Wiley.

Whang, H., Yong, S., \& Ko, E. (2016). Pop culture, destination images, and visit intentions: Theory and research on travel motivations of Chinese and Russian tourists. Journal of Business Research, 69(2), 631-641. https://doi.org/10.1016/j.jbusres.2015.06.020

Zarrad, H., \& Debabi, M. (2015). Analyzing the Effect of Electronic Word of Mouth on Tourists' attitude toward Destination and Travel Intention. International Research Journal of Social Sciences, 4(4), 53-60. Retrieved from www.isca.in 
E-Jurnal Manajemen, Vol. 9, No. 4, 2020 : 1230-1251

https://tekno.kompas.com/read/2019/05/16/03260037/apjii-jumlah-penggunainternet-di-indonesia-tembus-171-juta-jiwa

https://travel.detik.com/travel-news/d-2353478/kini-traveling-jadi-prioritaskedua-orang-indonesia 